\title{
The escalation of an armed conflict: a look at the antecedents of the confrontation between the Colombian state and the FARC
}

\section{La escalada de un conflicto armado: una mirada a los antecedentes del enfrentamiento entre el Estado colombiano y las FARC}

\author{
Nelson Cano-Holguín* \\ Escuela de Formación Infantería de Marina - \\ Colombia \\ ORCID iD: https://orcid.org/0000-0001-9425-5810 \\ nedcano@gmail.com \\ Javier Jiménez-Osorio \\ Universidad de San Buenaventura - Colombia \\ ORCID iD: https://orcid.org/0000-0002-5762-7758 \\ jjimenez@usbctg.edu.co \\ * Autor a quien debe ser dirigida la correspondencia
}

\author{
Fecha de recepción: 16/04/2020 \\ Fecha de evaluación: 08/05/2020 \\ Fecha de aceptación: 09/06/2020
}

Cómo citar: Cano-Holguín, N., \& Jiménez-Osorio, J. (2020). The escalation of an armed conflict: a look at the antecedents of the confrontation between the Colombian state and the FARC. Revista Cientifica Anfibios, 3(2), 101-106. https://doi.org/10.37979/afb.2020v3n2.78

\section{Resumen}

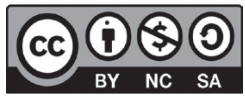

Atribución-NoComercial-CompartirIgual 4.0 Internacional

With one of the longest-running conflicts in the Western Hemisphere, the Colombian state has been facing an internal armed conflict against the FARC since the 1950s. Four milestones set the framework for the most important background in this conflict. The first one, with the murder of leader Jorge Eliecer Gaitan, unleashed acts of severe violence between liberals and conservatives; then, the second milestone was due to the creation of the "national front" that ended the disputes by rotating power between these political parties; however, other minority groups were not taken into account, giving rise to the third milestone, where the FARC guerrillas emerged by claiming a communist model, and the fourth milestone corresponds to heavy military strikes against this guerrilla group that forced the FARC to a negotiate peace accord. Considering the theory of escalation and stagnation of the armed conflict, this article aims at summarizing the background that has led to this conflict, which had its beginnings in political disputes but gradually escalated to become a serious problem that the country has been suffering.

Palabras clave:

Armed conflict; colombian state; FARC; escalation; confrontation.

\begin{abstract}
En uno de los conflictos más prolongados del Hemisferio Occidental, el Estado colombiano se enfrenta a un conflicto armado interno contra las FARC desde la década de 1950. Cuatro hitos establecen el marco de los antecedentes más importantes de este conflicto. El primero, con el asesinato del líder Jorge Eliécer Gaitán, desencadenó actos de severa violencia entre liberales y conservadores; luego, el segundo hito se debió a la creación del "frente nacional" que puso fin a las disputas mediante la rotación del poder entre estos partidos políticos; sin embargo, otros grupos minoritarios no fueron tomados en cuenta, dando lugar al tercer hito, donde la guerrilla de las FARC surgió reivindicando un modelo comunista, y el cuarto hito corresponde a los fuertes ataques militares contra este grupo guerrillero que obligaron a las FARC a negociar un acuerdo de paz. Considerando la teoría de la escalada y el estancamiento del conflicto armado, este artículo pretende resumir los antecedentes que
\end{abstract}


han llevado a este conflicto, que tuvo sus inicios en disputas políticas pero que poco a poco se fue intensificando hasta convertirse en un grave problema que el país ha venido sufriendo.

Palabras clave:

Conflicto armado; Estado colombiano; FARC; escalada; enfrentamiento.

\section{Introduction}

The Colombian state has been a country immersed in an armed conflict with the FARC guerrillas since the $1950 \mathrm{~s}$. To understand the background of this conflict, this article is divided into four sections. The first section presents the theory of conflict escalation, allowing for a holistic vision of the backdrop of the conflict and the failed peace process. The third section sets out the methodology and the fourth provides some conclusions.

\section{Background theory}

Escalation and De-escalation Theory of Dean G. Pruitt and Jeffrey Z. Rubin

Prut and Rubin express that the relationship between the two parties in conflict is relatively stable, alternating between periods of tension and periods of harmony; however, when conflicts intensify or increase, this dynamic still exists in the so-called "conflict spiral process" (Rubin, Pruitt and Kim 1994).

When power imbalances cause parties to resort to content strategies, or when ambitions are high, escalation makes conflicts more frequent, which drives both sides to think they can defeat each other. The spiral process intensifies the confrontation through a vicious cycle of actions and reactions. The actions of one side have provoked stronger and more disproportionate responses from the other side, so the aggression has continued and fed the spiral of violence.

The spike in violence has had consequences; for example, increased distrust between the parties and a more negative attitude towards their opponent. This view has created a tendency, for instance, among political leaders to give in to pressure from the military, which affects the behavior and internal motivation of the government and leads to extreme polarization while reducing the possibility of reconciliation. (Collins 2012).

According to the theory, when there is no substantial change in the balance of power and the conflict persists, a deadlock is reached. At this point, the situation may worsen, or the process of degradation may begin.

This impasse can be resolved by resignation, withdrawal or negotiation strategies. These three possibilities, nonetheless, are not simple; the first one is seen as weakness; the second is seen as cowardice or a betrayal of the principles defended; and the third represents the best option since it does not reflect a sense of defeat nor does it imply a debilitation of the interests and positions of each party; however, it does require a reconstruction of mutual trust that can be generated on the parties' own initiative or through a third party (Rubin, Pruitt and Kim 1994)

Given that any party has the capacity to effectively attack the key elements of the opponent, though not the capacity to destroy them but to change their perceptions and positions, this fact is what makes it possible to shift from an escalation in the conflict to a stalemate and vice versa (Collins, 2012)

Taking concepts such as escalation and stagnation as references, it is possible to better understand the background of the armed conflict between the Colombian state and the FARC.

\section{Background of the armed conflict between the Colombian state and the FARC}

Colombia has the dishonorable category of having one of the oldest armed conflicts in the western hemisphere, since its origins date back to the 1950s (Argáez 2003). However, practically since Bolivar's independence movement from the Spanish crown in 1810, Colombia's 
The escalation of an armed conflict: a look at the antecedents of the confrontation between the Colombian state and the FARC

history has been characterized by periods of social and political upheaval in its dual system of political parties. Between these two great political forces, the Conservative Party and the Liberal Party have always fought for political power. (Restrepo, Spagat and Vargas 2003).

In the most important incidents of conflict, some experts believe that the root cause of the clash is the "La Violencia" period between 1948 and 1958 (Acosta Núñez 2014; Schuster 2009). This timeframe began with the conservative government's onslaught on the Liberal Party due to the social protests triggered by the assassination of Liberal leader Jorge Eliecer Gaitán, giving rise to the Bogotazo, which spread throughout the country on April $9^{\text {th }}, 1948$. (Alape 1983). This situation led to the excessive use of force by conservative governments, and eventually gave way to hatred and excessive use of violence, forcing liberals to organize self-defense groups as protection against the government's attacks.

The solution to this particular incident of violence began with a coup d'état, which was implemented by the military forces led by General Rojas Pinilla against the government of President Laureano Gómez in 1953. (Rossi 1997).

After taking office, the military dictatorship gave amnesty and invited the Liberal Party's self-defense group to be demobilized. Most people have followed this call, with some exceptions. Later, in 1958, the political leaders of the two parties wanted to regain power from the military and agreed to a government treaty called the National Front (1958-1974) (Schuster 2009). This political agreement included the alternative exercise of power between the two parties every four years to share power and end disputes. The problem with the National Front is that it excludes all other political forces, including the Communist Party and other minorities. (Restrepo, Spagat, and Vargas 2003).

The Colombian Communist Party took advantage of this special fact of political exclusion to recruit those who had not benefited from the amnesties, which led to the swift establishment of a peasant self-defense orga- nization that did not demobilize during the military dictatorship and chose to continue armed resistance, thus creating a communist guerrilla in 1964, self-described as the Revolutionary Armed Forces of Colombia (known as FARC in Spanish) (Rosero 2011; Sánchez and del Mar Palau 2006).

The motive for the strife of the Revolutionary Armed Forces of Colombia is a series of social demands submitted by the peasant department to the central government, involving issues related to land ownership and acquisition. These propositions or reasons were described in the guerrilla agricultural plan (Rosero 2011; Sánchez and del Mar Palau 2006), which became the basis of their policy and also went on to oppose the establishment with a goal in mind to overthrow the government and impose communism nationwide. (Feldmann and Hinojosa 2009, 42-61; Johnson and Jonsson 2013,).

As for the FARC, the group identifies itself as a political-military organization with communist ideas; it uses guerrilla warfare tactics for its armed struggle and has used different types and levels of violence to control the civilian population wherever the group has made its presence, as well as a means to achieve the political objectives it pursues (Kalshoven 1983; Kolshoven 1972,). For many years, the group's military capacity was relatively low, until, in the 1980 s, they began to finance themselves directly or indirectly through the illegal drugs market. In this way, they increased their military capacity and, in the 1990 s, they became the most powerful illegal armed actor facing the Colombian government, to the point of threatening the democratic system and government institutions with an irregular army of approximately 20,000 men.

Although the FARC has not been the only armed actor in the conflict, this multiplicity of stakeholders has turned the Colombian conflict into one of the most difficult to deal with and understand, which has contributed to complicating the search for a definitive solution, especially if one considers the failure of the peace process. 
The negotiation of the peace process between the Colombian government and the FARC failed

Since the 1980s, the government of Colombia has sought a negotiated solution to the conflict, in one way or another, alongside all the illegal armed actors, including, among them, the FARC (Acosta Núñez 2014).

The first presidential administration to initiate a reconciliation process with the guerrilla groups in search of a negotiated peace accord was the government of Belisario Betancourt (1982-1986). In response to one of the FARC's most stringent demands, the government promoted the creation of a political party to openly represent them, called the Patriotic Union (Unión Patriótica or UP). However, most of their leaders were killed in a short period of time (Gómez-Suárez 2011). This situation not only put an end to the dialogues, but also sowed seeds of distrust in the national government by the FARC (Acosta Núñez 2014; Guerrero 2003).

During the government of César Gaviria Trujillo (1990-1994), some guerrilla movements demobilized, including the M-19 Movement, the Quintín Lame Revolutionary Movement, some factions of the National Liberation Army (ELN) and the Popular Liberation Army (ELP) (Fernández, García Duran and Sarmiento 2004), a process that was sealed with the enactment of a new Colombian Constitution in 1991 (Guerrero 2003). However, the FARC and most of the ELN decided to withdraw from the process and remain underground due to the assassination of some recently demobilized guerrilla leaders.

After almost a decade and having lived through one of the most violent periods of the Colombian conflict, between 1999 and 2002, the government of Andrés Pastrana Arango (19982002) initiated a peace negotiation process with the FARC known as the Caguán Dialogues, which came to an end in 2002, without having achieved an agreement (Loaiza 2012, ).

President Álvaro Uribe Vélez (2002-2010), after the failed peace talks in El Caguán, and upon heeding the clamor of public opinion, hardened the government's position against the guerrillas with the aim of undermining them militarily by implementing a series of combat policies and strategies, which, in a way, along with the international political context, wound up reversing the escalation process, substantially weakening the guerrilla groups and allowing for the creation of adequate conditions for the stalemate that prompted the origins of the current peace negotiations.

These negotiations have been finalized and are being implemented; furthermore, with the political will of all parties involved, it is possible to build a peaceful Colombia, which is, after all, the desire of all the Colombian people.

\section{Methods}

In order to better understand the background of the conflict between the Colombian state and the FARC guerrillas, this article carries out a bibliographical review based on the theory of escalation and stagnation of conflicts proposed by Rubin, Pruitt and Kim (1994). In this context, the background that allowed for the escalation and stagnation of this conflict, thus giving rise to the peace process, is summarized herein.

The practical results of this type of research are important sources of information because they provide an overview of research directions, problems and trends (Restrepo \& Urbizagástegui, 2016). This allows us not only to raise the antecedents of the Colombian state's conflict with the FARC, but also to study it from the theory of conflict escalation.

\section{Conclusions}

From the theory of armed conflict escalation and stagnation (Rubin, Pruitt and Kim 1994), a brief summary is presented on the antecedents of the armed conflict in Colombia with an emphasis on the failure of the peace process. This allows us to draw some conclusions referred to the points of escalation and stagnation in each moment.

With the assassination of leader Jorge Eliecer Gaitán, aggressions between the liberal and conservative sides began in the country; this escalation occurred because both factions 
The escalation of an armed conflict: a look at the antecedents of the confrontation between the Colombian state and the FARC

had lost mutual respect, leading to the onset of violent activities between them. Later on, with the stagnation of the conflict, wherein neither side seems to prevail, conditions are created for a negotiated solution through a power shift between liberals and conservatives. However, other minority groups, who were not part of this pact, triggered a new escalation that unleashed the conflict again.

Subsequently, with the demobilization of many of these armed groups thanks to the government's recognition of their political clout as a result of the failed peace process, there were still some communist minorities who, once again, escalated conflicts in an attempt to overthrow the national government and implement their communist model.

Finally, with the actions of Álvaro Uribe Vélez and several forceful military strikes against the FARC guerrillas, a new impasse was reached whereby a negotiated peace process was proposed, which today stands challenged by many contenders, thus throwing the future of the nation into a state of uncertainty.

\section{References}

Acosta Núñez, Milena Leonor. 2014. Introducción a los diálogos de paz en Colombia, un acercamiento histórico a los intentos de solución del conflicto.

Alape, Arturo. 1983. El bogotazo: Memorias del olvidoCasa de las Américas.

Argáez, Carlos Caballero. 2003. La estrategia de seguridad democrática y la economía colombiana: Un ensayo sobre la macroeconomía de la seguridadBanco de la República.

Collins, Randall. 2012. C-escalation and D-escalation A theory of the time-dynamics of conflict. American Sociological Review 77 (1): 1-20.

Feldmann, Andreas E., and Victor J. Hinojosa. 2009. Terrorism in colombia: Logic and sources of a multidimensional and ubiquitous phenomenon. Terrorism and Political Violence 21 (1): 4261.

Gómez-Suárez, Andrei. 2011. A Genocidal Geopolitical Conjuncture: Con-Textualising the Destruction of the Unión Patriótica in Colombia (1980s-2010).

Guerrero, Víctor. 2003. Breve historia de las amnistías e indultos en colombia. Foro Constitucional Iberoamericano.

Johnson, Kyle, and Michael Jonsson. 2013. Colombia: Ending the forever war? Survival 55 (1): $67-$ 86.

Kalshoven, Frits. 1983. Guerrilla and terrorism in internal armed conflict. Am.UL Rev. 33 : 67.

Kolshoven, F. 1972. Position of guerrilla fighters under the law of war, the. Mil.L.\& L.War Rev. 11 : 55.

Loaiza, Alderid Gutiérrez. 2012. Negociaciones de paz en colombia, 1982-2009. un estado del arte. Estudios Políticos 40 : 175-200.

Restrepo, Jorge A., Michael Spagat, and Juan F. Vargas. 2003a. The dynamics of the colombian civil conflict: A new data set.

Restrepo-Arango, C., \& Urbizagástegui-Alvarado, R. (2016). Acercamiento a los estudios Biliométricos, Cienciométricos e Infométricos en México. Informação \& Sociedade, 26(1). 
Rosero, Luis Fernando Trejos, 2011. Colombia y los estados unidos en los inicios de la guerra fría (1950-1966)"Raíces históricas del conflicto armado colombiano" colombia and the united states at the beginning of the cold war"(1950-1966)"Historical roots of the colombian armed conflict”. Memorias.Revista Digital De Historia Y Arqueología Desde El Caribe 8 (15): 47-74.

Rossi, Gonzalo Bermúdez. 1997. Pronunciamientos, conspiraciones y golpes de estado en colombia: De la conspiración septembrina al proceso 8000Ediciones" Expresion".

Rubin, Jeffrey Z., Dean G. Pruitt, and Sung Hee Kim. 1994. Social conflict: Escalation, stalemate, and settlement. Mcgraw-Hill Book Company.

Sánchez, Fabio, and María del Mar Palau. 2006. Conflict, decentralisation and local governance in colombia, 1974-2004CEDE.

Schuster, Sven. 2009. El primer gobierno del frente nacional y el "problema" de la violencia (19581962). 